\title{
FOOD SOCIO-POLITICS AND SHARIA FINANCE IN INDONESIA: AGRICULTURAL DEVELOPMENT IN ISLAMIC POLITICAL ECONOMIC PERSPECTIVES Hasan Mustapa ${ }^{1}$, Udin Saripudin ${ }^{2}$ \\ ${ }^{1}$ Faculty of Social and Political Science, UIN Sunan Gunung Djati Bandung Jl. A.H. Nasution No.105, Cipadung, Kec. Cibiru, Kota Bandung, Jawa Barat, Indonesia ${ }^{2}$ Fakultas Syariah, Universitas Islam Bandung J1. Tamansari No.1, Tamansari, Kec. Bandung Wetan, Kota Bandung, Jawa Barat, Indonesia \\ 11 kangmoez@uinsgd.ac.id; $*^{2}$ dr.saripudin34@gmail.com
}

\begin{abstract}
This paper seeks to examine the value of the government's role in enhancing investment from Islamic funding in the agricultural sector. This sector needs to be reinforced to serve as the basis for national food security. Agricultural landscape 's abundant potential will hopefully fulfill national needs and become a pillar of exports. This effort was hampered by the high risk that the capital aspects of the agricultural sector were faltering without certainty of profit making. With descriptive analysis the methodology used is qualitative. The result showed The economic prospects of Islamic agricultural policy were strong, but the lack of effective support for infrastructure gave rise to many weaknesses in socio-economic growth, socio-economic development, despite efforts to establish a sustainable society, public interests and reliable agricultural resources. It is worth considering the possible financing of the Hajj Financial Management Agency (HFMA) for the agricultural sector. The government must tighten regulations to foster a healthy partnership ecosystem between the Ministry of Agriculture, Islamic Financial Institutions, and high-quality agricultural resources.
\end{abstract}

Keywords: Islamic Funding; Agricultural Sector; Food Sosio-politics

*Corresponding author

\section{Introduction}

The rich agricultural ability in the paradise land of Indonesia should be enhanced for stabilisation of national food security. Unfortunately, this did not happen because of several problems plaguing the country, such as aspects of the concentration of social and political life on Java Island. The government took the initiative to move the capital to the island of Kalimantan, specifically in parts of the North Penajam Paser Regency and partly in the Kutai Kartanaegara Regency in the East Kalimantan Province to anticipate the inequality in growth (Kusuma, 2019). 
Some of the factors which cause this removal are Reinforcing food security where Java is a food security source while Kalimantan has 180 thousand hectares of government managed stock of land (Anastasia, 2019).

At the other hand, one of the consequences of lockdown policies in some countries projected to spread the Covid-19 pandemic (Coronavirus Disease), is the decreased availability of food. They tried to close it by restricting exports such as Russia, Kazakhstan and Ukraine, which limited exports of wheat seeds; and Vietnam and Thailand 's rice exports (Issetiabudi, 2020). The Indonesian government forecasts the supply of national strategic food for March to August 2020 including:

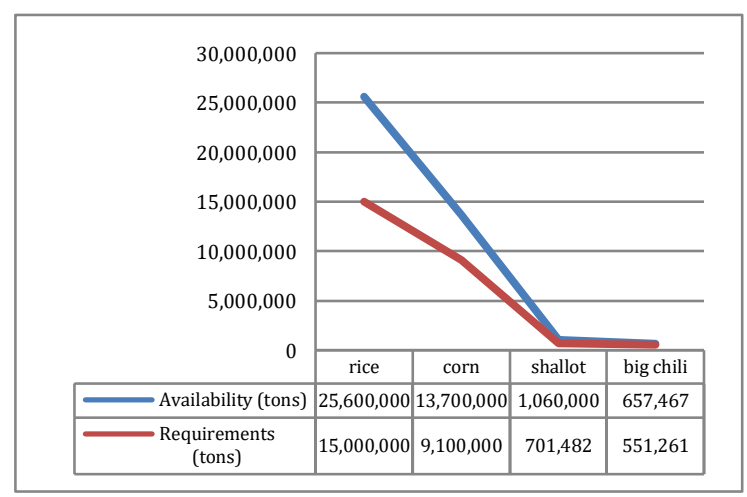

Figure 1. Food Availability

Estimation (Issetiabudi, 2020).

Weakening the performance of the agricultural sector can be addressed through risk mitigation policies such as implementing a labor-intensive community empowerment system with a cash-for - work model as well as government guarantees of the availability and access of food to farmers at affordable prices (Mujahidin, 2020).

Though the government has succeeded in rising exports and rising farmers' standard of living. Budget policies, however, have gradually shrunk, rapidly eroding agricultural land. The political change from agricultural to industrial transformation of the government's foreign policy jumped dramatically. Agricultural industries forced immediately to become broad-based industrialization (broad industry strategy) and hi-tech industries highly dependent on imported raw materials vulnerable to the movement of the rupiah exchange rate and the loss of foreign reserves.

Transformation in the strong countries is gradually undertaken by building the agricultural sector through industries generating agricultural production facilities. That was accompanied by support to the increasing manufacturing industry supporting the agricultural (agro-industry) sector. We moved into the machinery and metal sectors only after that (Noertjahyo, 2005; Suhendra, 2004).

ASEAN-China Free Trade Agreement (ACFTA) official presence in 2004 did not support the agricultural sector. The absence of incentives for farmers to promote 
increased production coupled with poor technical innovation and the logistics fragility and distribution network, resulting in low competitiveness of domestic products in agricultural products with fellow ASEAN countries such as Thailand, Malaysia and Vietnam; and from China for nonagricultural or manufacturing industries (Chandra, 2008: 12-15; Nasrudin, 2015: 21).

Restrictions on people's mobility and even the distribution of goods between countries as a result of the COVID-19 pandemic have created barriers to world food distribution. To overcome this barrier, the government increased the 2021 food security budget to IDR 104 trillion from IDR 80 trillion by 2020 (Julita S, 2021).

This government support is quite significant, however, other financing schemes through the Islamic financing channel can also be considered. Strategic collaboration between the Ministry of Agriculture and Islamic financial institutions can create long-term Islamic financing stability for agriculture. This may make it easier for the government to strengthen empowerment programs, particularly those involving human resources and micro, small, and mediumsized enterprises in the agricultural sector. This step is critical because individuals and groups can influence social, cultural, and personality systems in the context of longterm development (H. Mustapa et al., 2021: 154).

\section{The Previous Studies}

Capital assistance is very minimal for the agricultural industry (Saripudin et al., 2020). For this reason, the concept of Islamic financing was supposed to cover the shortcomings in the capital aspect Islamic financing is prospective enough to strengthen farm capital (Ashari \& Saptana, 2016). Both through the Integrated Sharia Agribusiness Partnership (KAST) (Sutawi, 2008) and investments in sharia financial institutions such as Sharia banking (Gumilang, 2017; Mughits \& Wulandari, 2016) and Sharia cooperatives, and Baitul Mal wa Tamwil (Maulida \& Yunani, 2017).

The low level of Islamic financing in the agricultural sector is due to the quality of human resources, managing the financial and the farm sector, which is still a relatively high risk (Larasati et al., 2017). Sharia financing for Islamic bank products can be carried out through mudharabah, musyarakah, muzara'ah, musaqah, bai' murabahah, bai istishna, bai' as-Salam and rahn schemes (Saragih, 2017). It is different from previous researches which are oriented towards applicative economics. This study examines the relationship between the 
implementation of public policy and the welfare of the community, especially in the context of the role of the government in strengthening the sociopolitical development of Islamic financial institutions to the conducive growth of the agricultural sector.

\section{Methods}

This research uses a qualitative approach to the case study method in three areas: political economy, growth of the agricultural sector and Islamic finance. It also outlined the role of government in making Islamic financial institutions more conducive to investing in the agricultural sector. Primary data sources for this study include food security policy data from the Republic of Indonesia's Ministry of Finance in 2021 and data on agricultural land depreciation in 2018 from the Central Statistics Agency (Sugiyono, 2017: 193). Data from institutions with the potential for Islamic financing to be used in the development of food and agricultural security are included in the additional data. Badan Pengelola Keuangan Haji (BPKH/Hajj financial management agency) is one of them (Sugiyono, 2017: 193).

The qualitative descriptive analysis method was used in this study, with the following steps: (a) Gathering data and information on food insecurity and suboptimal agricultural resource management; (b) Identifying existing issues and thoroughly analyzing several potential sharia financing options for the effectiveness of food security; (c) Designing a system by taking into account the system requirements required in accordance with the needs and conditions in the field; (d) Making recommendations on the implementation of a suitable sharia financing system for the benefit of policies to strengthen food security.

Furthermore, various data sources related to government policies on increasing the effectiveness of Islamic finance for agricultural products will be analyzed based on an understanding of the Islamic economic politics of (Rosdi, 2016: 256) where the dimensions of Islamic economic politics consist of socio-political development, socioeconomic development, balanced community development, public interest and source management of human resources (human resource management).

\section{Discussion}

\section{Islamic Political Economy}

There are three streams in political economy. The first view looks at political economy in terms of management, political processes and the role of ideology in a country's economic growth (Deliarnov, 2006: 8-10; Caporaso \& Levine, 1996: 45; Widjaja, 1982: 99; Jevon, 1879). The second 
insight further embraces the overall political economy including all aspects of economic, political or social issues such as problems of oppression, class conflicts, foreign debt, investment, capitalism development, and others (Bascom, 2009: 12; Devas, 2009: 25; Staniland, 1985: 37). The third idea looks at the political economy from economic relations and politics itself, namely economic interaction with the nation; or the state on the economy (Shively, 2011: 8).

(Choudhury et al. 1997) define Islamic political economy as the science of the relationship between government (shura) and the market sub-system. This definition shows that the political economy of Islam is an interaction approach taken to build human understanding of social acceptance and jurisprudential institutions in human behavior. Islamic economic politics will be able to realize optimal economic growth and have an impact on economic equity (Juliana et al., 2018).

Through a combination of Islamic economic philosophy and Islamic political philosophy, (Rosdi, 2016: 256) elaborates that Islamic economic politics should involve socio-political development, socioeconomic development, balanced community development development), public interest (public interest) and human resource management (human resource management). This is done for the reformation of the ummah (ummah reform [development]) based on the values of the Koran and al-Hadith.

In this study, Islamic political economy is a synergy of sociopolitical development, socio-economic development, balanced community development, public interest, human resource management for the reformation of the people based on Islamic values (Rosdi, 2016).

There are two approaches in looking at government intervention in the economy. The first approach is Adam Smith (17231790) who believes that the economy must be left to run on its own using free market forces and without government intervention. Through the invisible hand (invisible hand), the economy can create wealth and increase efficiency (Vivenza, 2008: 26-29; Samuels, 2008: 179-201).

Different views emerged after the economic crisis (The Great Depression) dramatically hit the world in the period 1929-1939, among others conveyed by John Maynard Keynes (1883-1946). He supported government intervention during the crisis period. The role of strategic government in bridging the gap between economic potential and actual output during times of crisis (Markwell, 2006). 
The Role of the State in Sharia Financing in the Agricultural Sector

Given the strategic importance of the role of credit in agricultural and rural development, it has encouraged governments (in many countries) to make it an important policy instrument. Credit is considered as one of the important tools to break the "low cycle of farming":

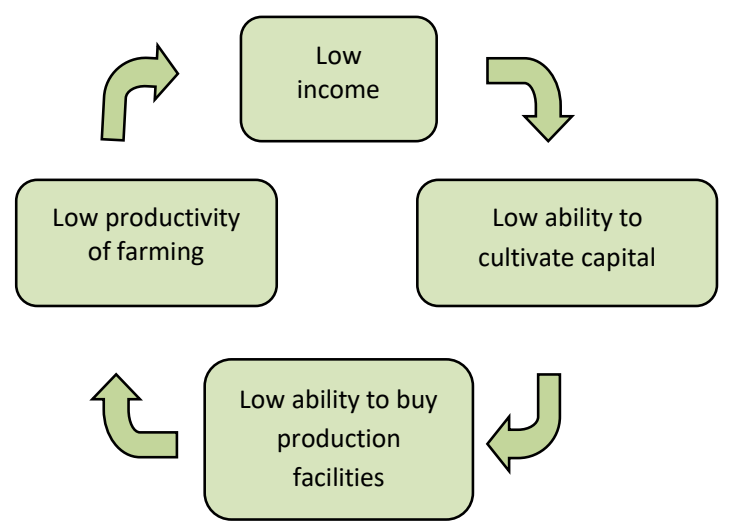

Figure 3. Low Cycle of Farming

(Tampubolon, 2002)

Government intervention for the improvement of Micro, Small and Medium Enterprises (MSMEs) is implemented with the issuance of Law Number 2008 About MSMEs Articles 7 and 8 which mandates the government and regional governments to grow the business climate by setting legislation and supporting policies.

In order to expand access to finance for MSMEs, on 5 November 2007 the Government launched the People's Business

Credit (KUR). This program is a continuation of the Farmers' Business Credit (KUT) budgeted at Rp 8 trillion per year which in 1998 began to falter and have an impact up to now along with the emergence of looseness and carelessness in its distribution.

One of the potential aspects of financing for farming capital is through Islamic financing. There are at least three Islamic banking orientations in countries with small, medium and large populations as shown in the following table.

Table 4. Orientation of Sharia Banking by Population

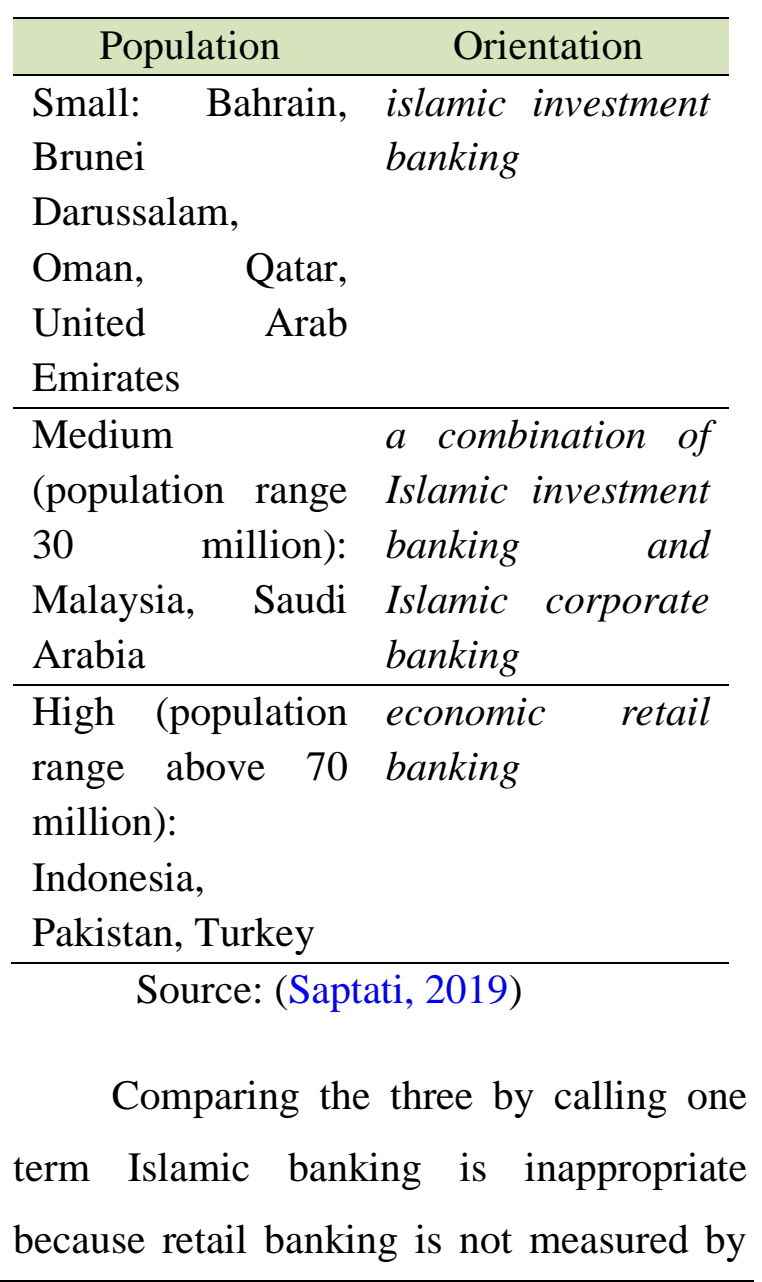


assets, but by how many people are involved. Furthermore, the role of the government in encouraging the growth of Sharia financing is contained in the Master Plan for Indonesian Sharia Finance Architecture (MISFA).

There are also concrete steps outlined in the Islamic financing strategy listed in MEKSI during the period 2019 2024, including: 1) Providing stimulus to BUMN / BUMD to increase the amount of Islamic financing through Sharia banks; 2) Increase the number of Sharia Commercial Banks (BUS), Sharia Business Units (UUS), and Sharia People's Credit Banks (BPRS) that are registered as Sharia People Business Credit Distribution Institutions (KUR); 3) Increase the amount of productive Sharia financing in the corporate sector and longterm financing (infrastructure).

The sharia-based financing strategy is expected to increase and contribute to driving the development of the sharia economy in Indonesia (Kemenkeu, 2019).

\section{Findings}

The political prospects of the Islamic economy in the agricultural sector, although bright, are still hampered, so the pace is slow. This is because the implementation of government policy does not yet fully have a holistic oriented prophetic awareness. This can be seen from the following research findings.

\section{Sociopolitical Development}

At the National Coordination Meeting for Agricultural Development in 2021, Deputy Minister of Finance (Wamenkeu) Suahasil Nazara said that the 2021 food security budget increased very significantly by $30 \%$ compared to the 2016 to 2020 budget, which trended down. If the 2020 budget is on the order of 80 trillion, by 2021 it will be 104 trillion with distribution details as follows.

\section{Table 5. Details of the 2021 Food Security Budget}

\begin{tabular}{|c|c|}
\hline Budget Allocation Details & $\begin{array}{l}\text { Amount } \\
\text { (IDR.) }\end{array}$ \\
\hline $\begin{array}{l}\text { Ministries and } \\
\text { Institutions }(K / L)\end{array}$ & 62,8 trillion \\
\hline $\begin{array}{l}\text { Ministry of Agriculture } \\
\text { Ministry of Maritime } \\
\text { Affairs and Fisheries } \\
\text { Department of Public } \\
\text { Works and Government } \\
\text { Services }\end{array}$ & $\begin{array}{r}21,8 \text { trillion } \\
6,7 \text { trillion }\end{array}$ \\
\hline Grants other than $K / L$ & 30,7 trillion \\
\hline Subsidy & 25,3 trillion \\
\hline Additional spending & 5,4 trillion \\
\hline $\begin{array}{l}\text { Transfer to Regions } \\
\text { Special Allocation Fund } \\
\text { in the form of DAK } \\
\text { irrigation, DAK for } \\
\text { agriculture, DAK for } \\
\text { marine and fisheries, } \\
\text { and DAK for non- } \\
\text { physical funds for food } \\
\text { security services }\end{array}$ & 5,6 trillion \\
\hline
\end{tabular}


Along with the growing needs of the population, the world of agriculture then adopted the term Agricultural Revolution 4.0, where agriculture is expected to involve digital technology in the development process. In Europe, there is a tendency for demographic crisis where the number of productive-aged population is smaller than the non-productive number so that the conversion of manpower to technology is needed so that the Industrial Revolution 4.0 in the agricultural sector is more dominant than other places (Rahayu, 2019).

Based on data from BPS through the land area figure obtained by the Area Sample Framework (KSA) methodology using data from satellite images of the National Aeronautics and Space Institute (LAPAN) and Geospatial Information Agency (BIG), a decline in agricultural land.

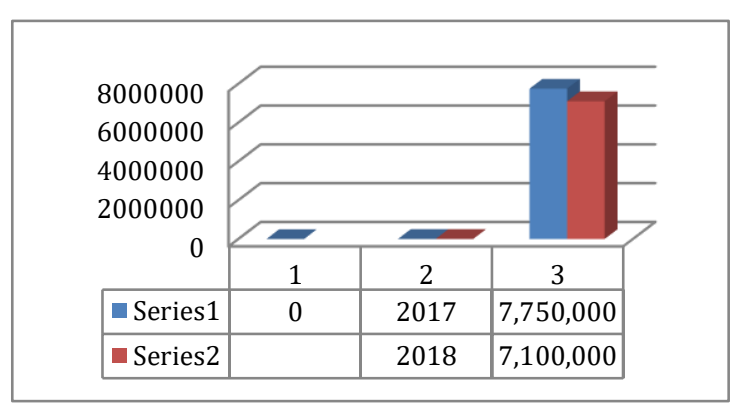

Figure 4. Depreciation of Agricultural

Land Area (Hectares) (BPS, 2018)

Meanwhile, to carry out food selfsufficiency, Indonesia is still experiencing difficulties due to the shrinking of agricultural land. Comparison with other countries is also very flat as shown in the following table.

Table 7. Comparison of

Agricultural Land Areas of Other

Countries

\begin{tabular}{lrrc}
\hline Country & $\begin{array}{c}\text { Agricultural } \\
\text { land }\end{array}$ & $\begin{array}{c}\text { Percentage } \\
\text { of Total } \\
\text { Land }\end{array}$ & $\begin{array}{c}\text { Population } \\
\text { to Land } \\
\text { Ratio } \\
\text { (People: } \\
\text { Hectares) }\end{array}$ \\
\hline Indonesia & $570.000 \mathrm{~km}^{2}$ & $31,5 \%$ & $1: 0,22$ \\
Thailand & $221.000 \mathrm{~km}^{2}$ & $43,3 \%$ & $1: 0,32$ \\
Australia & 4.000 .000 & $52,9 \%$ & $1: 16,67$ \\
& $\mathrm{~km}^{2}$ & & $1: 0,35$ \\
Cina & 5.000 .000 & $54,8 \%$ & 1 \\
& $\mathrm{~km}^{2}$ & & \\
\hline
\end{tabular}

Source: (CIPS, 2018)

From the budget strategy and shrinkage of agricultural land area, it is seen that the strategy for developing the agricultural industry needs to be changed. Therefore policy makers and decision makers are advised to invest in technological progress and offer all sectors of the economy various ways to promote agricultural innovation 4.0 (Zambon \& All., 2019: 11). Indonesia and China are potential countries in terms of quantity of human resources (Maelani et al., 2019).

\section{Sosioeconomic Development}

The government has contributed to the implementation of program credit policies, especially in the provision of subsidies to interest rates; to the cost of credit failure risk; and to administrative 
costs in distribution, service and credit withdrawal. In addition, indirect government subsidies for program credit are channeled to import fertilizers, seeds and medicines (Hermanto, 1992). So far there are two sources of agricultural capital credit aid budget namely the state budget and foreign cooperation assistance as follows.

Table 8. Sources of Agricultural Capital Assistance Credit Budget

\begin{tabular}{|c|c|}
\hline $\begin{array}{c}\text { Source of } \\
\text { Budget }\end{array}$ & Pro \\
\hline $\begin{array}{l}\text { State Budget } \\
\text { Revenue } \\
\text { (APBN) }\end{array}$ & $\begin{array}{l}\text { Mass Guidance Credit, } \\
\text { Farming Business } \\
\text { Credit, Food Security } \\
\text { Credit (KKP), } \\
\text { Agricultural Financing } \\
\text { Services Scheme } \\
\text { (SP3), Independent } \\
\text { Direct Assistance, } \\
\text { development of } \\
\text { Agribusiness } \\
\text { Microfinance } \\
\text { Institutions (LKMA) }\end{array}$ \\
\hline $\begin{array}{l}\text { Foreign } \\
\text { project }\end{array}$ & 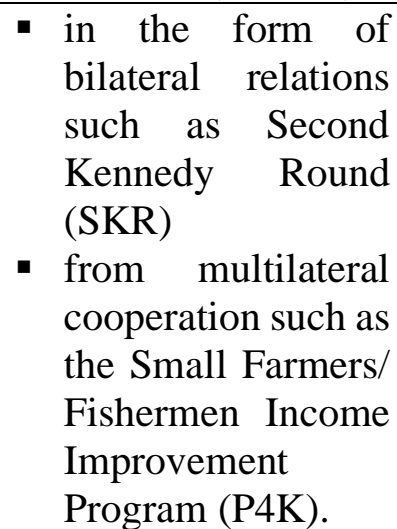 \\
\hline
\end{tabular}

Source: (Ashari, 2009)

Awareness of strengthening agriculture as a national food foundation is realized through the provision of budgets for national food programs such as: BIMAS program, Farming Business Credit (KUT), Food Security Credit (KKP), Community Direct Assistance (BLM), Strengthening Group Business Capital (PMUK), Institutions Agribusiness Microfinance, Small Farm / Fishermen Income Improvement Project.

A number of capital strengthening programs that have been implemented include: (a) direct assistance (BLT, BLM); (b) rolling assistance (BPLM, PMUK); (c) strengthening capital (DPM LUEP, PUAP); (d) interest subsidies (Bimas credit, KUT, $\mathrm{KKP}$ ); (e) approaching commercial (SP3, P4K, KUR). Unfortunately these various programs contain weaknesses. Among them:

\section{Table 9. Weaknesses in Agricultural \\ Program Policies}

\begin{tabular}{ll}
\hline Program & \multicolumn{2}{c}{ Weakness } \\
\hline Community & - less educating farmers to \\
Direct & be more professional in \\
Assistance & the use of funds. \\
& - The probability of a \\
& moral hazard is very \\
& large. \\
- & when the project ends the \\
& program also stops. \\
- reward and punishment & are very weak. \\
- Clearly measurable \\
output is \\
burdensome to the \\
government budget. \\
- This type of assistance is \\
effective for certain cases
\end{tabular}




\begin{tabular}{|c|c|}
\hline & $\begin{array}{l}\text { such as in a disaster area } \\
\text { or a very marginal area. }\end{array}$ \\
\hline $\begin{array}{l}\text { Subsidized } \\
\text { interest } \\
\text { credit }\end{array}$ & $\begin{array}{l}\text { - Strict requirements for } \\
\text { filing like a commercial } \\
\text { scheme make it difficult } \\
\text { for farmers to access. } \\
\text { - Duration of time is too } \\
\text { long from the credit } \\
\text { application until the } \\
\text { realization. } \\
\text { - collateral requirements } \\
\text { that require certified land } \\
\text { / BPKB to be difficult to } \\
\text { fulfill. } \\
\text { - In some cases, the } \\
\text { necessity of grouping } \\
\text { with a certain minimum } \\
\text { area is also a problem } \\
\text { especially for smallholder } \\
\text { farmers. } \\
\text { The necessity of grouping } \\
\text { also creates problems } \\
\text { when it comes to } \\
\text { determining the right } \\
\text { group leader } \\
\text { (management), in the } \\
\text { sense of having the } \\
\text { capacity, willingness to } \\
\text { work for the group and } \\
\text { being honest. }\end{array}$ \\
\hline Help rolling & $\begin{array}{l}\text { - Initially } \\
\text { Community Lirect } \\
\text { Assistance } \\
\text { (BPLM)/Strengthening } \\
\text { Group Business Capital } \\
\text { (PMUK) with revolving } \\
\text { funds aimed at forming } \\
\text { an embryo of an } \\
\text { independent } \\
\text { microfinance institution } \\
\text { (LKM) in groups with } \\
\text { initial capital from the } \\
\text { government. } \\
\text { - Very few of these MFIs } \\
\text { can be grown, even } \\
\text { though the funds that } \\
\text { have been disbursed with } \\
\text { the BPLM scheme are } \\
\text { very large. }\end{array}$ \\
\hline
\end{tabular}

Source: (Ashari, 2009)

\section{Balanced Community Development}

Various attempts were made by the central and regional government to form a socially and spiritually balanced society. In this case socially in the context of agricultural development and spiritually through religious educational institutions such as Islamic boarding schools. Education is a strategic aspect so it needs to be supported by appropriate intervention methods (Mustapa, 2018).

In 2018, the Minister of Agriculture launched a program of economic empowerment for people based on Islamic boarding schools towards the world food barn in Makassar. This program is a form and implementation of the new flow of the Indonesian economy through cooperatives and MSMEs. The basic idea is that if all people can be mobilized, Indonesia can certainly rule the world, becoming a super power country. The launch of the program was marked by the signing of a memorandum of understanding between the Minister of Agriculture and the Indonesian Ulema Council (MUI) and Koperasi Mitra Santri Nasional (KMSN).

The collaboration between MUI and KMSN is believed to be able to drive the progress of agricultural development, for example corn cultivation in Lampung, Bengkul, West Java, East Java, Central Java, 
which has been successful. If pesantren are moved together, agriculture will advance. MUI shares the responsibility of empowering the economy of the people because the ulema must take up space in eliminating poverty. KMSN is also a cooperative formed by MUI. KMSN has partnered with pesantren throughout Indonesia by developing corn, rice and karamba fish and other food commodities.

In addition, several regional leaders also launched the One Product One Pesantren (OPOP) as carried out by the Governor of East Java on August 22, 2019. There was also in West Java, the program was launched by the Governor of West Java Ridwal Kamil at Al Ittifaq Islamic Boarding School Ciburial Village Alam Endah Village, Rancabali Regency Bandung on December 12, 2018. Of the 9,000 Islamic residential schools in West Java, the OPOP program will begin with 600 schools. The Provincial Government of West Java will co-operate with the District Chief to implement this product One Pesantren One. According to data from BPS West Java in 2017, the province of West Java has 627 districts..

In this case, the more the quantity of community participation in government development programs increases, the more civil society will strengthen (Mustapa, 2019).

\section{Public Interest}

The politics of Islamic agriculture can be seen from the various policies that should be taken by the state in the field of agriculture, both the production sector (primary), the industrial sector (secondary) and the trade and service sector (tertiary). Therefore, when discussing the politics of Islamic agriculture, that means we will discuss agricultural politics in the production, processing (industry), and trade and services sectors.

To be effective, ideologies that are manifested in a system require strategies that are aligned with the goals to be achieved. According to Capra, "It must also have an effective way of bringing about socio-economic restructuring to enable a prompt transfer of resources from one use to another until the most efficient and equitable allocation and distribution has been attained". Without this harmony, no matter how good the strategy, will not be able to actualize even the best potential (Chapra, 1992: 4).

The experience of the Indonesian people shows that agricultural policy for the public interest is dynamic. During the Soekarno era (1959-1966) the political 
direction of the agricultural sector was emphasized in the inventory of agricultural and plantation lands. During the Soeharto era (1966-1998), the political direction of the agricultural sector was divided into two patterns, namely the pattern of food sovereignty and semi-industrialized agriculture. During the reform era, there was a dominance of the influence of foreign capitalism in legislation (Setiawati et al., 2020).

Legal politics based on the spirit of welfare of the people must be guided by a clean government and a non-corrupt bureaucracy. Without this, the development of all aspects including the agricultural sector, will be stagnant (Mustapa et al., 2020).

\section{Human Resource Management}

The low interest of millennials in the agricultural sector is a serious problem facing this country. Therefore, various attempts were made by the government to overcome this. Among them are Millennial Farmer Movement and Millennial Santri (Andri, 2019). The regeneration program is packaged in the Millennial Farmer and Santri Millennial movement, which are the two strategic program approaches of the Ministry of Agriculture. This program is intended to achieve national food independence through modernization of agriculture and mechanization of farming. This program is with the government's focus on developing Indonesian human resources.

Referring to the data of the Agricultural Human Resources and Extension Agency (BPPSDMP), the Millennial Farmers Movement was recorded as involving one million young farmers who are members of 40,000 farmer groups. They are spread throughout the provinces, from Aceh to Papua. Then divided into zones of commodity types such as food crops, horticulture, plantations and livestock.

The Prospect of Empowering the Agriculture Sector through the Hajj Financial Management Agency (BPKH)

For investment in the agricultural sector and empowerment of the people, financial instruments such as the Hajj Financial Management Agency, an institution established July 26, 2017 can be considered directed at investment financing. This is because of the extraordinary potential of this institution in raising funds for Muslim communities who will go on Hajj. During 2018 the Hajj Financial Management Agency (BPKH) said that the managed hajj funds were recorded at Rp 113 trillion, exceeding the Rp 111 trillion target. $32 \%$ of the funds are included in third party funds (DPK) of Islamic commercial banks and national banking sharia business units. 
$50 \%$ placed in sharia banking and $50 \%$ sharia securities. in $2018 \mathrm{BPKH}$ registered as many as 550,000 pilgrims but exceeded the target of 664,000 registrants.

The total value of the benefits of the Hajj Financial Management Board (BPKH) as shown in the table.

Table 11. Total Value of Benefits and Allocations

\begin{tabular}{cl}
\hline Year & $\begin{array}{c}\text { Return on Investment from } \\
\text { the Hajj Fund (IDR.) }\end{array}$ \\
\hline 2018 & 6 Trillion (increased 28\%) \\
2017 & 4,7 Trillion \\
\hline
\end{tabular}

\begin{tabular}{ll}
\hline Alocation & \multicolumn{2}{c}{ amount (percentage) } \\
\hline $\begin{array}{l}\text { returns on } \\
\text { prospective } \\
\text { pilgrims }\end{array}$ & $\begin{array}{l}\text { distribution of benefits to } \\
\text { prospective pilgrims must get } \\
\text { the approval of the House of }\end{array}$ \\
& $\begin{array}{l}\text { Representatives (DPR) of the } \\
\text { Republic of Indonesia }\end{array}$ \\
BPKH & $\begin{array}{l}5 \% \text { of the total value of } \\
\text { operational } \\
\text { costs }\end{array}$
\end{tabular}

Source: (Yoyok, 2018).

BPKH recorded the remaining Hajj funds in 2020 to reach IDR 143.1 billion. Last year's realization exceeded the Hajj pay target set by BPKH of IDR 139.5 trillion. In comparison with the 2019 Hajj fund balance of IDR 124.32 billion, the 2020 figure increased by $15 \%$. This shows that the people have made inscribing on pilgrimage a priority, even in the midst of the crisis. About 69.6 per cent of the funds were invested, while the remaining 30.4 per cent were invested in Shariah banks. With the increase in managed funds, the value of benefits provided to the prospective waiting hajj pilgrims also increased, namely Rp7.46 trillion or grew 2.33 percent compared to the previous year amounting to Rp7.29 trillion (Rini, 2021).

The author sees that the benefit scheme has been implemented by the Ministry of Finance through the Education Fund Management Agency (LPDP). If a similar scheme can be applied to BPKH, then just consolidate with relevant stakeholders to strengthen the judicial foundation both sharply (MUI, Ministry of Religion, Islamic Organizations, etc.) or legally positive.

Tabung Haji Malaysia, as one of the best fund management tools hajj in the world, manages funds for investment and various other enterprises. The funds are invested in the finance sector and Islamic enterprises. The financial investment is in the form of funding, buying securities, while the business managed by Tabung Haji includes hotels, property, plantations, and various other businesses (BPKH, 2019: 143).

In this case, the government's communications strategy is important for socializing the various aspects of the 
benefits of each policy to be implemented (Rachiamatie et al., 2020). Besides, as one of the Islamic financial instruments, the effectiveness and efficiency of the management of the Ummah's institutions is expected to provide a multiplier effect in reviving the people's economy, especially for those affected by Covid 19 (Effendi, 2021).

\section{Conclusion}

Food sociopolitical development in order to be effective, requires a number of instruments. These include: regulations that can guarantee price stability and market availability for agricultural products, profarmer policy programs that seek to raise the standard of living of farmers, create conducive conditions for a balanced farming community with physical and spiritual needs, and the synergy of the central and regional governments supporting the birth of a generation of farmers only from millennial.

It is time, the government looked at Islamic religious instruments both in education such as Islamic boarding schools, or finance such as banking and Islamic cooperatives. In addition, potential financing patterns from Islamic financial institutions such as the Hajj Financial Management Agency (BPKH) to revive the agricultural sector, should be considered.
In contrast to the path of financial institutions, the risks inherent in BPKH are more than in the legal and operational aspects. As long as there are Muslims in Indonesia, the financial energy input of this institution will be preserved. Of course, this should also look at the readiness of the farming community to increase professionalism in managing stimulant funds.

With a scheme that can reflect the policies of the Ministry of Finance with the Education Fund Management Agency to support the education sector.

\section{Bibliography}

Anastasia, C. A. P. (2019). Alasan Ibu Kota Pindah ke Kalimantan Timur, dari Risiko Bencana hingga Terletak di Tengah Indonesia. August 26.

Andri, K. B. (2019). Santri: Energi Baru Pertanian Indonesia. October 22.

Ashari. (2009). OPTIMALISASI KEBIJAKAN KREDIT PROGRAM SEKTOR PERTANIAN DI INDONESIA Policy Optimization of Credit Program for Agricultural Sector in Indonesia Pengalaman krisis moneter pada tahun 1998 telah menyadarkan semua pihak bahwa sektor pertanian memiliki peran st. Analisis Kebijakan Pertanian, 7, 2142. 
Ashari, \& Saptana. (2016). Prospek Pembiayaan Syariah untuk Sektor Pertanian. Forum Penelitian Agro Ekonomi, $23(2)$, https://doi.org/10.21082/fae.v23n2.20 05.132-147

Bascom, J. (2009). Political Economy. BiblioBazaar LLC.

BPKH, B. I. (2019). Apa dan Bagaimana Investasi keuangan haji BPKH. Badan Pengelola Keuangan Haji.

BPS. (2018). RAPBN 2019.

Caporaso, J. A., \& Levine, D. P. (1992).

Theories of Political Economy. Cambridge University Press.

Chandra, A. C. (2008). Indonesia di Tengah Kesepakatan Perdagangan Bebas

Bilateral Asean-China: Satu Kajian Kritis. Seminar: Setelah Air Mata Kita Kering: 10 Tahun Setelah Tragedi Tionghoa Mei 1998, 12-15.

Chapra, M. U. (1992). Islam and The

Economic Challenge. The Islamic

Foundation and The International

Institute of Islamic Thought.

Choudhury, M. A., M. Z., A., \& Salleh, M. S. (1997). Islamic Political Economy In Capitalist-Globalization. Utusan Publications and Distributors Sdn.Bhd dan International Project on Islamic Political Economy (IPIPE) Universiti Sains Malaysia.

CIPS. (2018). Luas Lahan Pertanian Antar
Negara.

Deliarnov. (2006). Ekonomi Politik. Erlangga.

Devas, C. S. (2009). Political Economy. BiblioBazaar LLC.

Effendi, M. R. (2021). DEVELOPMENT OF CASH WAQF BENEFITS SYNERGY FOUNDATION IN THE ECONOMIC EMPOWERMENT OF THE UMMAT. 5(1), 29-39.

Finance, M. of. (2021). Anggaran Ketahanan Pangan 2021 Ditingkatkan Hingga 30\%. Janyary 11.

Gumilang, R. R. (2017). Model Pembiayaan Syariah Bank Muamalat untuk Sektor Pertanian. $\quad$ Coopetition, $\quad 8(2$ (November)), 119-128. https://doi.org/10.19105/iqtishadia.v3i 2.1081

Hermanto. (1992). Keragaan Penyaluran Kredit Pertanian: Suatu Analisis Data Makro. In A. H. Taryoto, Abunawan, Soentoro, \& Hermanto (Eds.), Perkembangan Perkreditan di Indonesia. Pusat Penelitian Sosial Ekonomi Pertanian Badan Penelitian dan Pengembangan Pertanian.

Issetiabudi, D. E. (2020). Isu Keamanan Pangan saat Pandemi, Bukan Sekadar Keresahan Obrolan Warung Kopi. April 18.

Jevon, W. S. (1998). Political economy: Science primers (Second). Forgotten 
Books.

Juliana, J., Marlina, R., Saadillah, R., \& Mariam, S. (2018). Pertumbuhan Dan Pemerataan Ekonomi Perspekif Politik Ekonomi Islam. Amwaluna: Jurnal Ekonomi Dan Keuangan Syariah, 2(2), 120-131.

https://doi.org/10.29313/amwaluna.v2i 2.3824

Julita S, L. (2021). Ngeri Krisis, Anggaran

Ketahanan Pangan 2021 Naik 30\%. January 12 .

Kemenkeu, R. (2019). Ini Cara Pemerintah

Tingkatkan Pertumbuhan Pembiayaan Syariah. May 06.

Kusuma, H. (2019). Resmi! Jokowi

Putuskan Ibu Kota RI Pindah ke Kaltim. August 26.

Larasati, P. P., Fitriyah, S., Widiastuti, T., \&

Berkah, D. (2017). Pembiayaan Syariah di Sektor Ekonomi: Solusi Permasalahan Riba dalam Perspektif Sosial dan Ekonomi. Jurnal Ekonomi

Dan Bisnis Islam, $3(2$ (JuliDesember)), 139-157.

Maelani, R., Mustapa, H., \& Saifullah, I. (2019). Indonesian Human Progressivism: Human Resources Quantity in Educational Philosophy Perspective. Jurnal Pendidikan Universitas Garut, 13(01), 86-102. Markwell, D. (2006). John Maynard Keynes and International Relations: Economic
Paths to War and Peace. Oxford University Press.

Maulida, S., \& Yunani, A. (2017). Masalah dan Solusi Model Pengembangan Pembiayaan Pertanian dari Aspek Keuangan Syari' ah. CAKRAWALA: Jurnal Studi Islam, XII(2), 91-100.

Mughits, M., \& Wulandari, R. (2016). Kontribusi Pembiayaan Bank Syariah untuk Sektor Pertanian di Indonesia Contribution of Islamic Bank Financing for Agricultural Sector in Indonesia. Jurnal Al-Muzara'ah, 4(1), 61.

Mujahidin, I. (2020). Strategi Penyediaan Pangan Menghadapi Pandemi. April 22.

Mustapa, H. (2018). Memorizing Constructivism: Assimilation and Accomodation Islamic Studies Teaching Method in Majelis Taklim. Jurnal Pendidikan Universitas Garut, 12(01), 53-63.

Mustapa, H. (2019). Political Regional Tourism in Civil Society Perspective (Profile of Development Strategy of Situ Bagendit Tourism Object, Banyuresmi District, Garut Regency, West Java Province). Politicon, 1(1), $24-50$.

Mustapa, H., Bakti, A. F., Ansori, F., Saripudin, U., \& Budiansyah, Y. (2020). Good Governance and 
Corruption in the View of Syafruddin Prawiranegara ( 1911-1989 ). International Journal of Psychosocial Rehabilitation, 24(04), 36-50. https://doi.org/10.37200/IJPR/V24I4/P R201631

Nasrudin, et. A. (2015). Dampak AseanChina Free Trade Agreement (Acfta) Terhadap Kinerja Perekonomian Dan Sektor Pertanian Indonesia. Buletin Ilmiah Litbang Perdagangan (July), 9(1), 1-23.

Noertjahyo. (2005). Dari ladang sampai Kabinet: Menggugat Nasib Petani. Kompas.

Rachiamatie, A., Fitria, R., Suryadi, K., \& Ceha, R. (2020). Strategi Komunikasi Pariwisata Halal Studi Kasus Implementasi Halal Hotel di Indonesia dan Thailand. Amwaluna: Jurnal Ekonomi Dan Keuangan Syariah, 4(1), $55-74$.

https://doi.org/https://doi.org/10.29313 /amwaluna.v4i1.5256

Rahayu, N. (2019). Begini Revolusi Industri 4.0 di Sektor Pertanian. February 14.

Rini, A. S. (2021). BPKH Buka-bukaan Strategi Investasi di Tahun Kerbau Logam. January 13.

Rosdi, M. S. M. (2016). The Balance of Economics and Political Science in Islamic Political Economy. Journal of Economic and Social Thought, 3(2),
252-264.

https://doi.org/10.1453/jest.v3i1.668

Samuels, W. (2008). Adam Smith's Invisible Hand. In S. J. Peart \& D. M. Levy (Eds.), The Street Porter and the Philosopher: Conversations on Analytical Egalitarianism. University of Michigan Press.

Saptati, R. (2019). Modal Besar Memimpin Pasar. Media Keuangan Transparansi Informasi Kebijakan Fiskal VOL. XIV / NO. 140, 25-26.

Saragih, F. H. (2017). Pembiayaan Syariah Sektor Pertanian. Jurnal Agrica, 10(2), 112.

https://doi.org/10.31289/agrica.v10i2. 1458

Saripudin, U., Djamil, F., \& Rodoni, A. (2020). The Zakat, Infaq, and Alms Farmer Economic Empowerment Model. Library Philosophy and Practice, January, 1.

Setiawati, T. W., Ferdiana, T., \& Paksi, M. (2020). Politik Hukum Pertanian Indonesia Dalam Menghadapi Tantangan Global. Jurnal Hukum Lus Quia Lustum, 26(3), 585-608. https://doi.org/10.20885/iustum.vol26. iss 3 .art8

Shively, W. P. (2011). Power and Choice An Introduction To Political Science (12th ed.). Mc Graw Hill International Edition. 
Staniland, M. (1985). What Is Political Economy: A Study of Social Theory and Underdevelopment. Yale University.

Sugiyono. (2017). Metode Penelitian Kuantitatif Kualitatif dan $R \& D$. Alfabeta.

Suhendra, S. (2004). Analisis Struktur Sektor Ekonomi Indonesia, Analisis Metode Input-Output. Jurnal Ekonomi Dan Bisnis, 9(2), 55-65.

Sutawi. (2008). Pembiayaan Syariah pada Usaha Mikro, Kecil dan Menengah Sektor Agribisnis dengan Pola Kemitraan. Jurnal Keuangan Dan Perbankan, 12(3), 447-458.

Tampubolon, S. M. H. (2002). Kredit untuk Petani. In Harianto, R. Pambudy, S. Tungkot, \& Burhanudin (Eds.), Suara dari Bogor Sistem dan Usaha Agribisnis: Kacamata sang Pemikir (pp. 116-119). Pusat Studi Pembangunan IPB dan USESE Fondation.

Vivenza, G. (2008). A Note on Adam Smith's First Invisible Hand. The Adam Smith Review, 4, 26-29.

Widjaja, A. (1982). Budaya politik dan pembangunan ekonomi. LP3ES.

Yoyok. (2018). BPKH: Nilai manfaat dana haji capai $R p 6$ triliun pada tahun 2018. Desember 14.

Zambon, I., \& All., E. (2019). Revolution
4.0: Industry vs. Agriculture in a Future Development for SMEs. Processes, 7(36), 1-16. 